（3）諸住正太郎，後藤正治，塚上八十治，茅野秀夫：日 本金属学会誌, 39(1975), 801.

(4) G.R.Smolik and C.W.Chen : J.Nucl. Mat., $35(1970), 94$.

(5) J.Venetch, A.A.Johnson and K.Mukherjee : J.Nucl. Mat., 34(1970), 343.

(6) F.A.Smidt, Ir. : Rad. Eff., 10(1971), 205.

(7) M. Bocek, H. Bohm and W. Schneider : J. Nucl. Mat., 40(1971), 249.

(8) M.Eto, K.Fukaya and K.Shiraishi : J.Nucl. Mat., 48 (1973), 365.

(9) M.S.Wechsler, D.G.Alexander, R.Bajaj and O.N.Carlson : Proc. Interna. Conf. Defects and Defect Clusters in BCC Metals and Their Alloys, (R. J. Arsenault ed.), Nuclear Metallurgy, $18(1973), 127$.
(10) J. M. Williams, W. E. Brundage and J.T. Stanley : Met. Sci. J., 2(1968), 100.

(11) J. H. Perepezko, R. F. Murphy and A. A. Johnson : Phil. Mag., 19(1969), 1.

(12) J.T.Stanley, J.M.Williams, W. E. Brundage and M.S.Wechsler : Acta Met., 20(1972), 191.

(13) A.A.Johnson : Scripta Met., 7(1973), 1.

(14) M. S. Wechsler, J.M. Williams and J.T. Stanley : Scripta Met., 7(1973), 7.

(15) Y.Adda : Radiation-Induced Voids in Metals, (J.W.Corbett and L.C. Ianniello ed.), USAEC, (1972), p.31.

\title{
微量の $\mathrm{Al}$ を添加した $\mathrm{Fe}-14 \mathrm{Cr}$ 合金の 含湿酸素中における高温酸化
}

\section{岡部広 交* 池偉 夫*}

Hirobumi Okabe and Hideo Ike : High Temperature Oxidation of Fe-14Cr Alloys with Small Additions of Al in Wet Oxygen. A study has been made on the isothermal oxidation behaviour of $\mathrm{Fe}-14 \mathrm{Cr}-\mathrm{Al}$ alloys containing up to $2.0 \% \mathrm{Al}$ in $1 \mathrm{~atm} \mathrm{O}_{2} / \mathrm{H}_{2} \mathrm{O}$ vapour mixtures in the temperature range 900 to $1200^{\circ} \mathrm{C}$. Compared with the previously reported behaviour in dry $\mathrm{O}_{2}$, little change has been observed on $0.3 \% \mathrm{Al}$ alloy at and below $1100^{\circ} \mathrm{C}$. The good oxidation resistance of the alloy is explained to be due mainly to the stability against moisture of the scale rich in $\mathrm{Cr}_{2} \mathrm{O}_{3}$, the nucleation and growth of which being brought about preferentially by an internal oxidation zone of dispersed $\alpha-\mathrm{Al}_{2} \mathrm{O}_{3}$ particles. At $1200^{\circ} \mathrm{C}$ water vapour begins to have effects on the alloy in such a way that it accelerates the initiation and growth of warts formed exclusively along the specimen edges. The structure of warts formed on the alloy after breakaway is double-layered and has been characterized by accumulation of Al just beneath the outermost part of the inner layer. This accumulation of $\mathrm{Al}$ has been considered to be the result of agglomeration of the dispersed $\alpha-\mathrm{Al}_{2} \mathrm{O}_{3}$ particles during the growth of the warts. Two types of breakaway are found to occur in 0.1 and $0.8 \% \mathrm{Al}$ alloys. One appears predominantly along the specimen edges at high temperatures, with the Al accumulation as in the case of $0.3 \% \mathrm{Al}$ alloy, and the other, with no significant accumulation of $\mathrm{Al}$, occurs uniformly on the specimen surface at relatively low temperatures and a high level of water vapour contents. Under the oxidizing condition where the latter type of breakaway occurs, development of the internal oxidation zone of well-developed and dispersed $\alpha-\mathrm{Al}_{2} \mathrm{O}_{3}$ particles is not sufficient in these two alloys so that the preferential formation of the $\mathrm{Cr}_{2} \mathrm{O}_{3}$-rich scale cannot be fully established. The alloys are thus subject to an intense effect of moisture as observed. The oxidation resistance of $2.0 \% \mathrm{Al}$ alloy is high at temperatures below $1000^{\circ} \mathrm{C}$, beyond which it decreases more rapidly than in dry $\mathrm{O}_{2}$.

(Received April 19, 1978)

\section{I. 緒言}

$\mathrm{Fe}-\mathrm{Cr}$ 合金の高温酸化挙動に及洔す水蒸気の影響につ いてはいくつかの研究(1) (4)が報告されているが，その影 響は必ずしも単純ではない.Caplan ら (1)(2)は数種の実用
鋼について 870 1 $093^{\circ} \mathrm{C}$ で空気中に乱りる高温酸化に及 活す水分の效果を調べ，酸化速度は水分の存在によって tp.446 (27Cr) ではむしる減少するが，Cr 含有量の少ない $410(11 \mathrm{Cr}), 430(17 \mathrm{Cr})$ p $302(19 \mathrm{Cr}-9 \mathrm{Ni})$ では異常に加速さ れるといら結果を得心。虫た, Fujii ら ${ }^{(3)}$ 本蒸気と Ar

\footnotetext{
* 大阪府立工業技術研究所 (Osaka Prefectural Industrial Research Institute, Osaka)
} 
ガスの混合雲围気中で高温酸化実験を行ない，低 Cr 合金 $(0 \sim 15 \mathrm{Cr})$ は $800 \sim 1100^{\circ} \mathrm{C}$ で線型（急速）酸化挙動を示す ことを見出している。一力, Kvernes ら ${ }^{(5 ;}$ は 1 4.5\%A1 を含む Fe-13Cr-Al 合金を $980^{\circ} \mathrm{C}$ 以下の温度に叔てて水 分を含む空気中で酸化させた結果，4.5\%A1では殆んど 水分の影響を受けないが，低 $\mathrm{Al}$ 合金の場合は酸化速度が 加速されること。また, 温度が低い場合は $\mathrm{A} 1$ 量の増加が 酸化抵抗を高めるが，高温になるとこの効果は失なわれる と報告している。

著者ら ${ }^{(6)}$ は先に0.1〜2.0\% Al を含さ Fe-14Cr-Al 合金 の $1200^{\circ} \mathrm{C}$ 采の酸素ガス雾囲気中における高温酸化挙動 について調べ, $1000^{\circ} \mathrm{C}$ での低温では $2.0 \% \mathrm{Al}$ 合金も比 較的優れた酎酸化性を示すが， $1100^{\circ} \mathrm{C}$ 以上では $0.3 \% \mathrm{Al}$ が影著に優れた酸化抵抗を示すといら実験結果を得た。こ れは A1 の内部酸化之密接に関係して $\mathrm{Cr}_{2} \mathrm{O}_{3}$ の濃度の高い 保護性皮膜が優先して形成，安定性が持続するためである と推察されている。

本研究においては，先の報告で用いた Fe-14Cr-A1 合

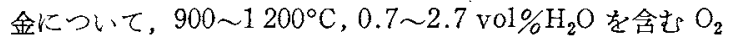
ガス中で酸化実験を行ない，水分の影響について検討を加 えたので報告する。

\section{II. 実 験 方 法}

実験に用いた合金は電解 Fe と電解 Cr および Fe-Al (50〜 50\%) 母合金を $1 \mathrm{~kg}$ の真空溶解装置により，アルゴ ン $10 \mathrm{kN} / \mathrm{m}^{2}$ の雲囲気中で溶製した，合金の化学組成を

Table 1 に示す．溶解試料は熱間生延および冷間圧延に より約 $1 \mathrm{~mm}$ 厚の板とした。酸化試験片の形状はほほ $15 \times 10 \times 1 \mathrm{~mm}$ とし，これを $1000^{\circ} \mathrm{C} て ゙ 3 \mathrm{~h}$ 真空烇なまし $\left(\sim 2.7 \times 10^{-3} \mathrm{~N} / \mathrm{m}^{2}\right)$ を行ない，さらに, $600 \mathrm{grit} の \mathrm{SiC}$ 紙 で研摩仕上げした後，アセトン，エチルアルコールで脱脂 洗浄し，酸化実験に供した，酸化実験はPID 制御された 稼型シリコニット炉と自記天科(島津 RL,-200)を用いて行 なった。

水蒸気を有する酸素雾囲気の調整は流量計により $5 \mathrm{~cm}^{3} / \mathrm{s}$ に調節した $\mathrm{O}_{2}$ ガス(紣度 $99.8 \%$ 以上)を一定の温 度に保たれた蒸留水の入ったフラスコに導入し，0.7, 1.4 扎よび $2.7 \mathrm{vol} \% \mathrm{H}_{2} \mathrm{O}$ となるよら自記温度湿度計で監視し た。湿度のばらつきはいずれも \pm 0.1 vol\% $\mathrm{H}_{2} \mathrm{O}$ 以内に制 御した。この水蒸気を含さ $\mathrm{O}_{2}$ ガスを酸化炉下部より流入
させ 1 気压の酸化雾田気とした。酸化試験温度は900 $1200^{\circ} \mathrm{C}$ の $100^{\circ} \mathrm{C}$ 間隔とし連続酸化の重量変化を湘定し た。な拉，酸化試験片は炉温打よび $\mathrm{O}_{2}$ ガス中の水分含有 量が所定の条件に達したのち，炉内に吊下げ 1 実験 1 試料 とした，酸化した試料の酸化生成物の同定ならびに各元素 分布の決定はX線回折，光学拉よび走查型電顕，ならびに これに附属したX線マイクロアナライザー(SMU-DDS) で 観察打よび測定を行なった。

\section{III. 実 験 結 果}

\section{1. 酸化増㽬曲線}

$\mathrm{A}(\mathrm{A} 1$ を含有世す），B(0.1\% A1 含有 $), \mathrm{C}(0.3 \% \mathrm{~A} 1$ 含 有)，D(0.8\% A1 含有) および $\mathrm{E}(2.0 \% \mathrm{Al}$ 含有 $)$ 合金を $900 \sim 1200^{\circ} \mathrm{C}$ の各温度で，0.7, 1.4 およ゙ 2.7 vo1\% $\mathrm{H}_{2} \mathrm{O}$ (以下，\%の記す) の3 種類の水分を含导酸素雲囲気(以 下 wet $\mathrm{O}_{2}$ という) 中で 24 恃間(以下，特記ない場合は 24 時間を省略して温度，湿度のみ記す)酸化させ，酸化增量 と時間の関係を示したのが Fig.1〜5である。ただし， $\mathrm{CrO}_{3}$ の形での蒸発量 ${ }^{(7)(8)}$ は無視した。

$\mathrm{A}$ 合金については $900^{\circ} \mathrm{C} て ゙$ 水分の影響は殆んど認めら れないが，1000ㄷ 以上になると大きく影響を受ける。す なわち, $1000^{\circ} \mathrm{C}, 1.4 \%$ $1100^{\circ} \mathrm{C}, 0.7 \%$ における酸化速度 は $1200^{\circ} \mathrm{C}$ で水蒸気を加えない $\mathrm{O}_{2}$ ガス（以下， dry $\mathrm{O}_{2}$ と い5) 中のそれを大きく上回っている。

$\mathrm{B}$ 合 金は $1200^{\circ} \mathrm{C}$, 全試験湿度と $1000^{\circ} \mathrm{C}, 1100^{\circ} \mathrm{C}$ の $2.7 \%$ を除いて氷分の影響を殆えど受けず dry $\mathrm{O}_{2}$ 中と同 しくく良い酸化抵抗を示す。しかしながら，1000 $\mathrm{C}, 1100^{\circ} \mathrm{C}$

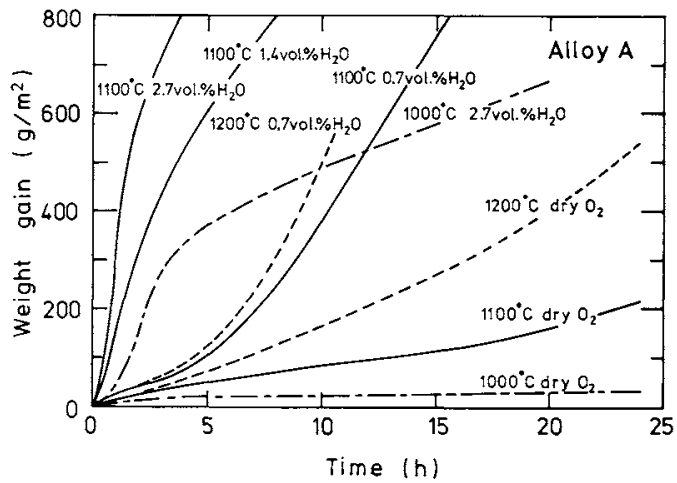

Fig.1 Oxidation of alloy A between 1000 and $1200^{\circ} \mathrm{C}$ in $1 \mathrm{~atm}$ wet oxygen.

Table 1 Chemical composition of the alloys tested(wt\%).

\begin{tabular}{|c|c|c|c|c|c|c|c|}
\hline \multirow{2}{*}{$\begin{array}{l}\text { Alloy } \\
\text { designation }\end{array}$} & \multirow{2}{*}{ Nominal composition } & \multicolumn{6}{|c|}{ Analyzed composition } \\
\hline & & $\mathrm{Cr}$ & $\mathrm{Al}$ & $\mathrm{C}$ & $\mathrm{O}$ & $\mathrm{N}$ & $\mathrm{Fe}$ \\
\hline $\begin{array}{l}\text { A } \\
\text { B } \\
\text { C } \\
\text { D } \\
\text { E }\end{array}$ & $\begin{array}{l}\mathrm{Fe}-14 \mathrm{Cr} \\
\mathrm{Fe}-14 \mathrm{Cr}-0.1 \mathrm{Al} \\
\mathrm{Fe}-14 \mathrm{Cr}-0.3 \mathrm{Al} \\
\mathrm{Fe}-14 \mathrm{Cr}-0.8 \mathrm{Al} \\
\mathrm{Fe}-14 \mathrm{Cr}-2.0 \mathrm{Al}\end{array}$ & $\begin{array}{l}14.00 \\
14.05 \\
14.10 \\
14.25 \\
14.35\end{array}$ & $\begin{array}{l}\overline{0.13} \\
0.28 \\
0.75 \\
2.04\end{array}$ & $\begin{array}{l}0.0012 \\
0.0014 \\
0.0013 \\
0.0023 \\
0.0032\end{array}$ & $\begin{array}{l}0.0082 \\
0.0024 \\
0.0019 \\
0.0014 \\
0.0015\end{array}$ & $\begin{array}{l}0.0056 \\
0.0010 \\
0.0050 \\
0.0025 \\
0.0016\end{array}$ & $\begin{array}{l}\text { Bal. } \\
\text { Bal. } \\
\text { Bal. } \\
\text { Bal. } \\
\text { Bal. }\end{array}$ \\
\hline
\end{tabular}




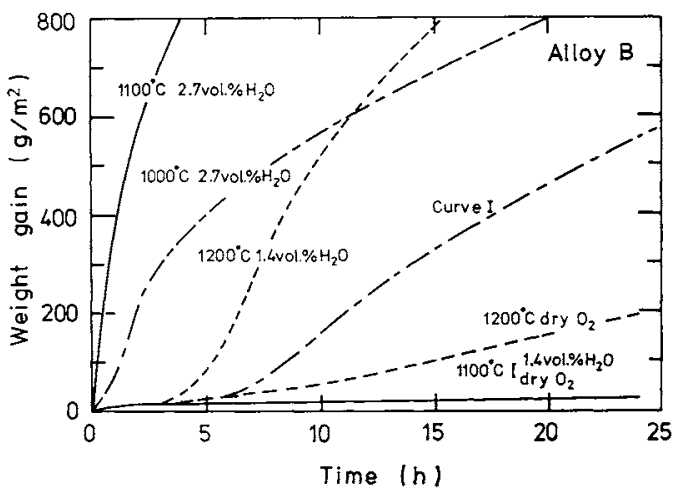

Fig.2 Oxidation of alloy $B$ between 1000 and $1200^{\circ} \mathrm{C}$ in $1 \mathrm{~atm}$ wet oxygen.



Fig. 3 Oxidation of alloy $\mathrm{C}$ at 1100 and $1200^{\circ} \mathrm{C}$ in 1 atm wet oxygen.

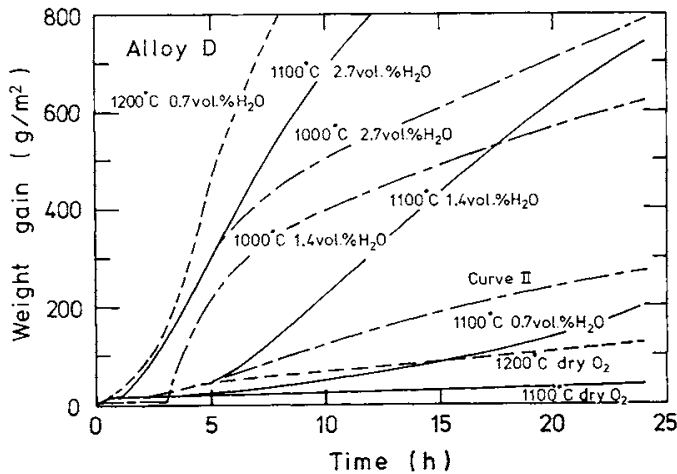

Fig.4 Oxidation of alloy $\mathrm{D}$ between 1000 and $1200^{\circ} \mathrm{C}$ in $1 \mathrm{~atm}$ wet oxygen.

の $2.7 \%$ にててA合金のそれと殆んど変らない程度の 影響を受け，酸化速度は増し，A1添加の効果は殆えぞ認 められなくなる。

$\mathrm{C}$ 合金は $1100^{\circ} \mathrm{C}$ なでの各試験湿度に打ける酸化增量は dry $\mathrm{O}_{2}$ 中と殆んど変化はなく，水分に対して $\mathrm{Al}$ 添加が 非常に有効に働き，優れた酸化抵抗を示している。

$\mathrm{D}$ 合金は $900^{\circ} \mathrm{C}$ で水分の影響は殆んどみられないが， $1000^{\circ} \mathrm{C}$ で強く影響を受けるようになり，A1 添加の効果は 僅かしか認められない，水分が堌加すると breakaway の

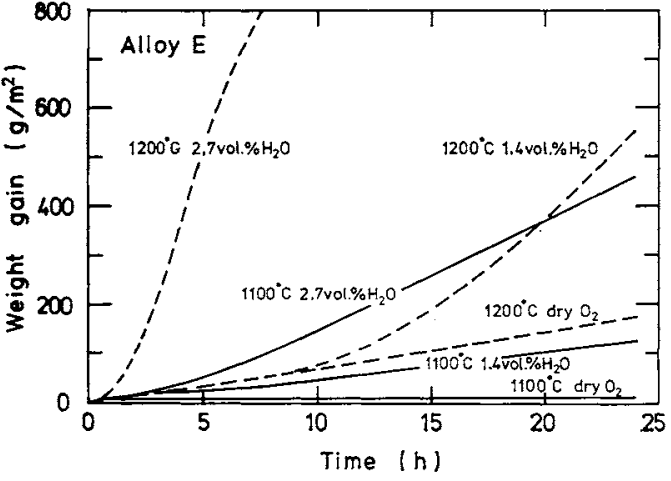

Fig.5 Oxidation of alloy $\mathrm{E}$ at 1100 and $1200^{\circ} \mathrm{C}$ in 1 atm wet oxygen.

時期を早め，温度が高くなると急速に増量する㑯向にある。

E合金については， $1000^{\circ} \mathrm{C} の 2.7 \%$ で荲かに水分の影 響を受けるが，それ以下の湿度では酸化堌量への影䇾は認 められない. $1100^{\circ} \mathrm{C}, 1200^{\circ} \mathrm{C}$ になると水分の增加と共に 酸化増量为增寸。

以上, Al 添加量の異なる合金について 各温度，湿度に おける酸化增量曲線をdry $\mathrm{O}_{2}$ 中に括ける曲線と比較した が，一般的に，それぞれの酸化举動を単一の理想的な速度 方程式で表珿することは困難であり，酸化過程はきわめて 複雑である。

\section{2. 酸化後の外観}

酸化後の試料外観の特徽は酸化条件 (温度，湿度)によっ て強い影響を受け，また，その受け方は $\mathrm{A} 1$ 量によって異 なる。

A合金: dry $\mathrm{O}_{2}$ 中では $1000^{\circ} \mathrm{C}$ をで異常酸化物 (nodule またはwart)の発生は認められない, wet $\mathrm{O}_{2}$ 中では $1000^{\circ} \mathrm{C}$ 以上で異常酸化が全面にわたって発生し，表面を

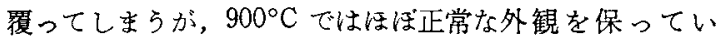
る、たたしここの場合, 湿度が高くなるにつれて異常酸化 の前兆とするれる現象が一部に発生する。

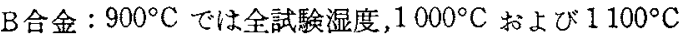
では 1.4\%すで異常酸化現象はみられない.Photo.1(a)に 示すように $1000^{\circ} \mathrm{C}, 1100^{\circ} \mathrm{C}, 2.7 \%$ にると異常酸化が 発生する。このように異常酸化が全表面に执いてほ注同時 に発生与る型(以下, Type X といら) と, Photo.1(b)に 示すよらに試料周辺で異常酸化が発生し，徐々に全表面を 覆いPhoto.1(d)k至る型(以下, Type Y という)の 2 種 がある. $1200^{\circ} \mathrm{C}$ では全試験湿度範围で後者，すなから， Type $\mathrm{Y}$ となる。な和, Type Xはdry $\mathrm{O}_{2}$ 中での全試 験温度範团内で $\mathrm{A}$ 合金の一部を除いて観察されず, wet $\mathrm{O}_{2}$ 中，とくに，高湿度で比較的低温の $1000^{\circ} \mathrm{C}, 1100^{\circ} \mathrm{C}$ に特 有の型である。

C 合金: $1100^{\circ} \mathrm{C}$ 以下では試料外観に殆ん亡゙変化はみら れない. $1200^{\circ} \mathrm{C}$ になるとPhoto.1(c)に示したような Type Y の異常酸化が発生し，Photo.1(d)に示したよう 
(a)

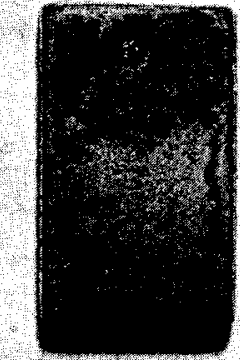

(t)

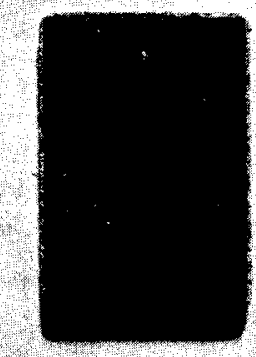

(b)

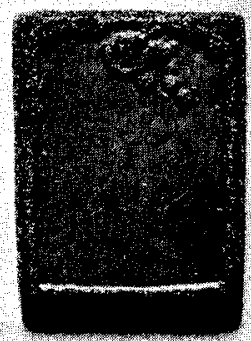

(g)

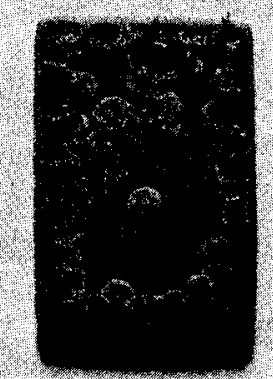

(c)

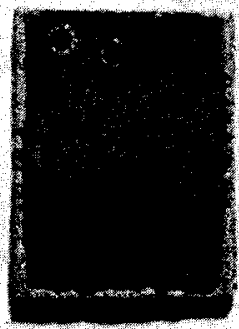

(h)

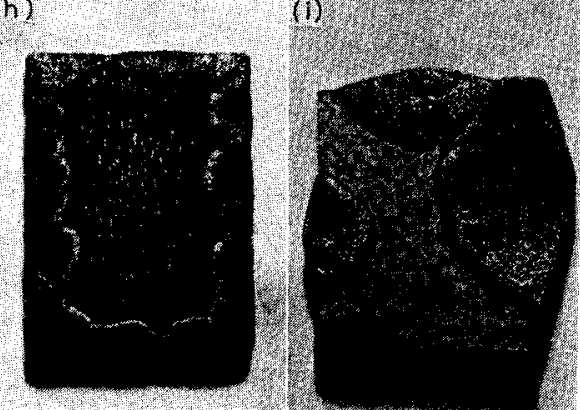

(e)

(d)

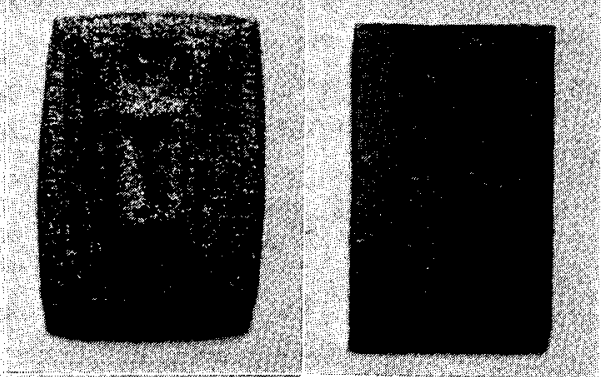

Photo.1 Appearance of specimens of alloys B, C, D and E oxidized in $1 \mathrm{~atm}$ wet oxygen. (a) alloy $\mathrm{B}, 1000^{\circ} \mathrm{C}, 2.7 \%, 24 \mathrm{~h}$, (b) $\mathrm{B}, 1200^{\circ} \mathrm{C}, 0.7 \%, 8 \mathrm{~h}$, (c) $\mathrm{C}, 1200^{\circ} \mathrm{C}, 0.7 \%, 24 \mathrm{~h}$, (d) alloy C, $1200^{\circ} \mathrm{C}, 2.7 \%, 24 \mathrm{~h}$, (e) $\mathrm{D}, 1000^{\circ} \mathrm{C}, 0.7 \%, 24 \mathrm{~h}$, (f) $\mathrm{D}, 1000^{\circ} \mathrm{C}, 2.7 \%, 24 \mathrm{~h}$, (g) alloy $\mathrm{D}, 1100^{\circ} \mathrm{C}, 1.4 \%, 23 \mathrm{~h}$, (h) $\mathrm{E}, 1100^{\circ} \mathrm{C}, 2.7 \%, 24 \mathrm{~h}$, (i) $\mathrm{E}, 1200^{\circ} \mathrm{C}, 1.4 \%, 24 \mathrm{~h}$.

に, $2.7 \%$ に㧧いてつい全面が異常酸化で覆われてしま 5 .

D合金: $900^{\circ} \mathrm{C}$ を除く全ての温度で異常酸化の発生がみ られたが，その形式は複雑である。すなわ占，1000兄で は，異常酸化はPhoto.1(e)に示すよ5に試料の全表面に 点在する形で発生し，湿度が高い場合 (1.4\%)はこれが全 表面を覆いType X の形態をとる(Photo.1(f))， $1100^{\circ} \mathrm{C}$ になるとPhoto.1 (g) に示すよ5に，試料の周㬰と表面の 一般部から同時に wart(\&たは nodule) が発生し，成長す る。更に， $1200^{\circ} \mathrm{C}$ では表面の一般部での異常酸化の発生 はまれにしかなく，殆んど周边部からの wart のみが認め られるよらになり，B合金の場合と同様 Type Yになる。 $\mathrm{E}$ 合金：異常酸化の発生は $1000^{\circ} \mathrm{C}, 2.7 \%$ および $1100^{\circ} \mathrm{C}$ 以上の wet $\mathrm{O}_{2}$ 中でみられ，形式は Photo.1(h)に示すよ らにType Yに類似している。ただしこの場合， Photo.1 (b), (c) で示したものとは異なり, 試料の厚みを 貫通して内部へ侵食して行くという特徽をるつ。これは Photo.1(g)で示したような D合金の一部でも堇かにみら れる傾向である。 wart の発生は全周囲からほぼ同時に発 生するとは限らず $24 \mathrm{~h}$ 後でるな和正常な状態を保ってい る部分が認められることが多い(Photo.1(i))。

\section{3. 酸化皮膜の断面構造}

皮膜に和ける Fe の組成比がやや高くなる攧问に专る点 を除けば，正常部の断面構造はdry $\mathrm{O}_{2}$ 中での酸化による 場合と比較して大きな差異は認められない，酸化条件が苛 酷になると異常酸化の発生様式や皮膜構造も複雑になる。
特に，試料外観で述べたようにB和よびD合金では Type $\mathrm{X}$ と Type $\mathrm{Y}$ があり皮膜構造の特性も異なる。以下，こ れらの点に留意しつつ各合金の代表的皮膜構造について述 ベる、ただし，A合金については13Cr ですでに報告(5)さ れているのでここでは省略する。

B合金： $900^{\circ} \mathrm{C}$ 全試験湿度, $1000^{\circ} \mathrm{C}, 1100^{\circ} \mathrm{C}, 0.7$ お よび $1.4 \%$ にいては，いわゆる正常部のみであり， $\alpha-\mathrm{Al}_{2} \mathrm{O}_{3}$ の内部酸化層を伴う $(\mathrm{Fe}, \mathrm{Cr})_{2} \mathrm{O}_{3}$ 皮膜，与なわち，

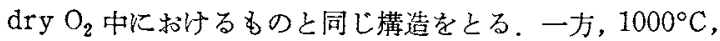
$1100^{\circ} \mathrm{C}, 2.7 \%$ 和よび $1200^{\circ} \mathrm{C}$ の全試験湿度に扣いて形 成された異常酸化皮膜の構造は内層，外層の 2 層からなっ ている。外層は外側に $\mathrm{Fe}_{2} \mathrm{O}_{3}$, 内側に $\mathrm{Fe}_{3} \mathrm{O}_{4}$ とからなり, 内層は一部 $(\mathrm{Fe}, \mathrm{Cr})$ スピネル型の複酸化物も認められる が主体は $(\mathrm{Fe}, \mathrm{Cr})_{2} \mathrm{O}_{3}$ である。媵述の $\mathrm{C}, \mathrm{D}$ およ゙゙ $\mathrm{E}$ 合金 の異常酸化部の構造も基本的には B合金と同じである。

Fig. 6 は $1000^{\circ} \mathrm{C} ， 2.7 \%$ に忛る皮膜断面の EPMAによ

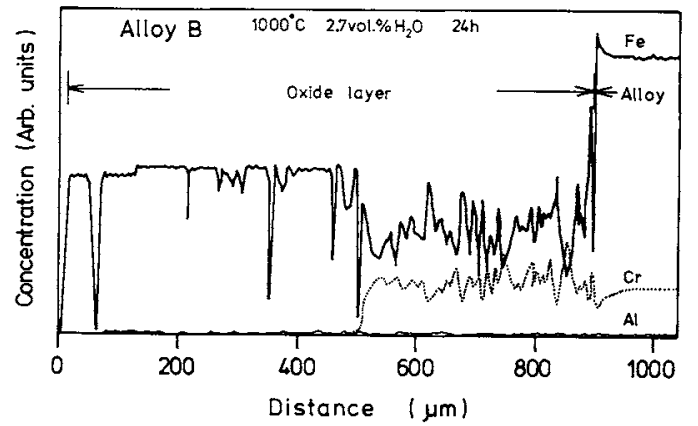

Fig.6 Microprobe scans showing the concentration profiles for $\mathrm{Fe}, \mathrm{Cr}$ and $\mathrm{Al}$ along the dark line in Photo.2(a). 


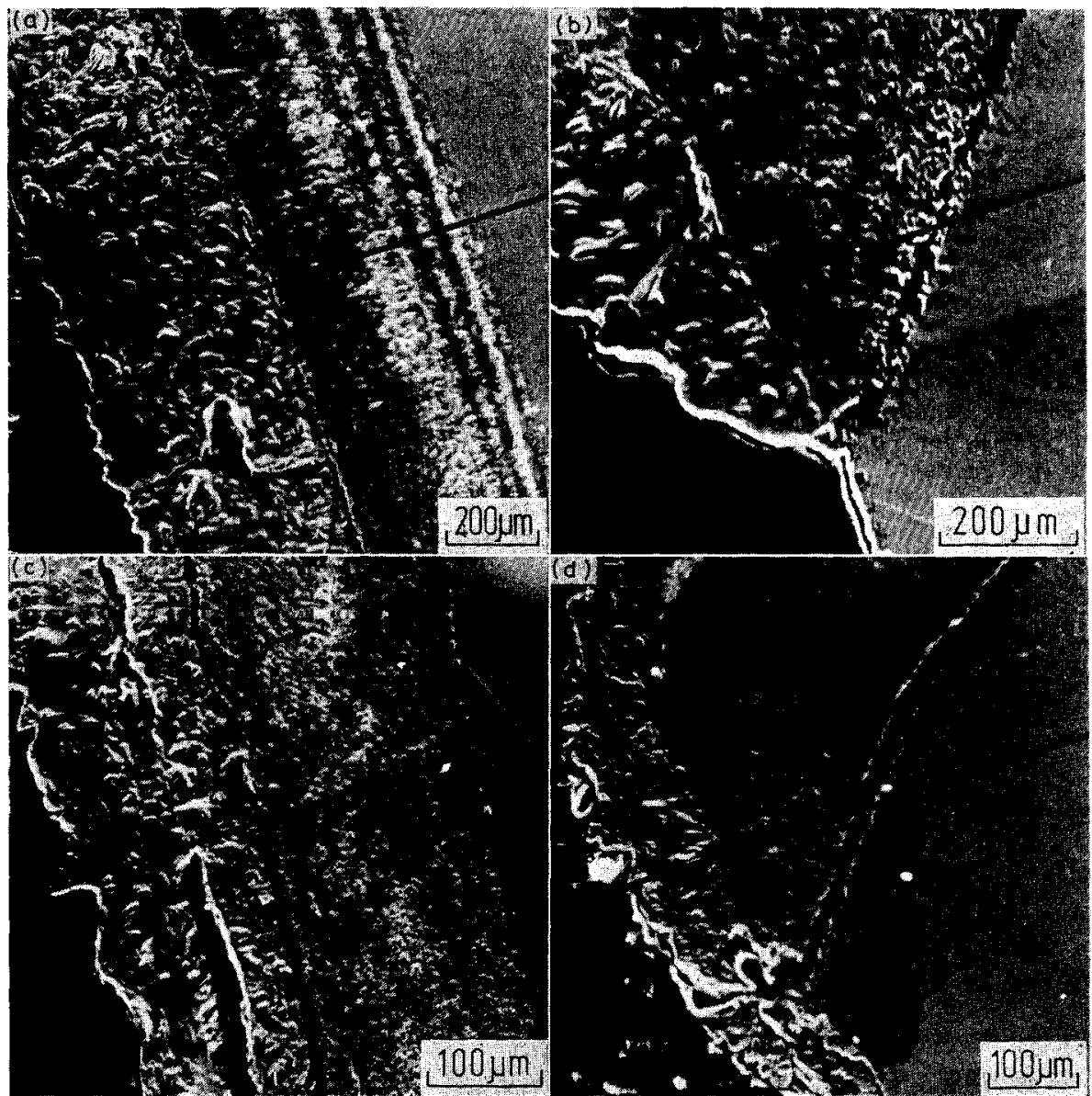

Photo.2 Microstructures of alloys B, C, D and E oxidized in 1 atm wet oxygen.

る line profile である．全表面にわたってほぼ同時に異 常酸化が起こるType X の場合はこれからわかるよらに， A1の集積が認められない。な和ここでPhoto.2は各合 金の皮膜断面の 2 次電子像の一例であり，線分析(Fig.6〜 9)をした走查部分を黒線で示している，一方，周围から異 常酸化が起こる条件，例点ば， $1200^{\circ} \mathrm{C}, 0.7 \%$ で $8 \mathrm{~h}$ 酸化 した試料の Al 元素分布を調ベると，後述のC 合金と同様 に内層に Al の集積が認められる。

$\mathrm{C}$ 合金 : $1100^{\circ} \mathrm{C}$ 以下では湿度に無関係に，皮膜構造は dry $\mathrm{O}_{2}$ 中の6の之同様， $\alpha-\mathrm{Al}_{2} \mathrm{O}_{3}$ の内部酸化層を伴 $5 \mathrm{Cr}$ 濃度の非常儿高い( $\mathrm{Fe}, \mathrm{Cr})_{2} \mathrm{O}_{3}$ からなる構造をとる。 $1200^{\circ} \mathrm{C}$ に必いてみられる異常酸化皮膜の構造はFig.7に 示すように内層と外層の間にCrの集積がみられ，その内 側にA1の集積が認められる。これは初期に形成された保 護性の良い, $\mathrm{Cr}$ 浇度の高い $(\mathrm{Fe}, \mathrm{Cr})_{2} \mathrm{O}_{3}$ 皮膜と $\alpha-\mathrm{A}_{2} \mathrm{O}_{3}$ 内 部酸化粒子が一部移動集団化して残存したものと考党られ る.

$\mathrm{D}$ 合金： $900^{\circ} \mathrm{C}$ 全試験湿度にお子る皮膜構造は dry $\mathrm{O}_{2}$ 中の場合々殆えど同じである。 $1000^{\circ} \mathrm{C}, 1.4$ および $2.7 \%$ では早くも breakawayを起こし，その異常酸化部 の構造はB合金の $1000^{\circ} \mathrm{C} と 1100^{\circ} \mathrm{C}$ の $2.7 \%$ 場合とほ

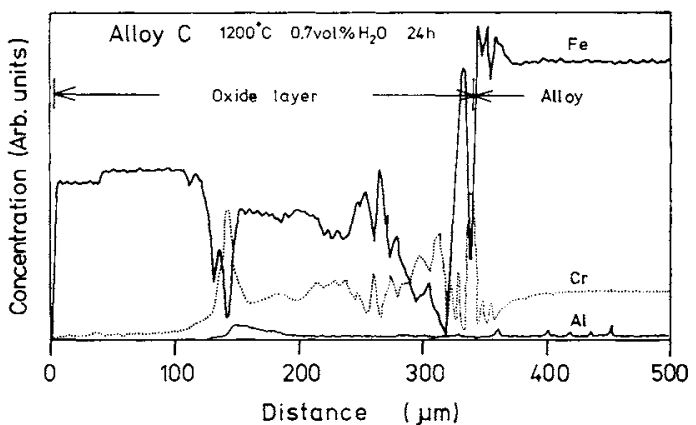

Fig.7 Microprobe scans showing the concentration profiles for $\mathrm{Fe}, \mathrm{Cr}$ and $\mathrm{Al}$ along the dark line in Photo.2(b).

ぼ同じで，内層に叔けるA1の集積は認められない。な お, $1000^{\circ} \mathrm{C}, 0.7 \%$ に壮る点在する小さな wart の皮膜 構造もこれと同椂である。しかし，Type Yをとる異常 酸化部の元素分布はFig.8に示すとまり，ここでる内層 でのAl の集積がみられる。

$\mathrm{E}$ 合金: $: 1000^{\circ} \mathrm{C}, 1.4 \%$ までの試験条件に招いては dry $\mathrm{O}_{2}$ 中と同じような皮膜構造をとるが， $1000^{\circ} \mathrm{C}, 2.7 \%$ よ び $1100^{\circ} \mathrm{C}$ 以上になると水分の影響を受计 Photo.2(d)に 


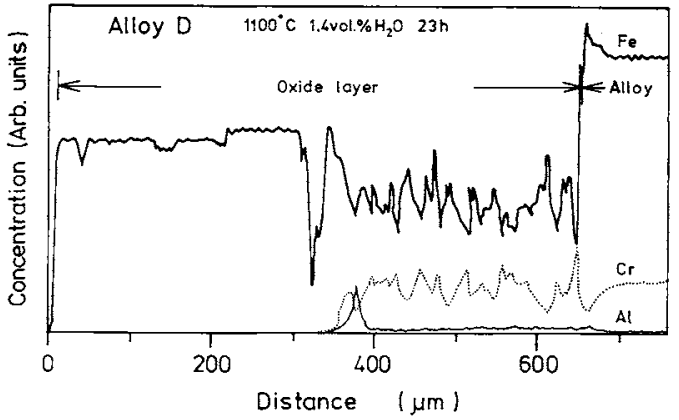

Fig.8 Microprobe scans showing the concentration profiles for $\mathrm{Fe}, \mathrm{Cr}$ and $\mathrm{Al}$ along the dark line in Photo. $2(\mathrm{c})$.

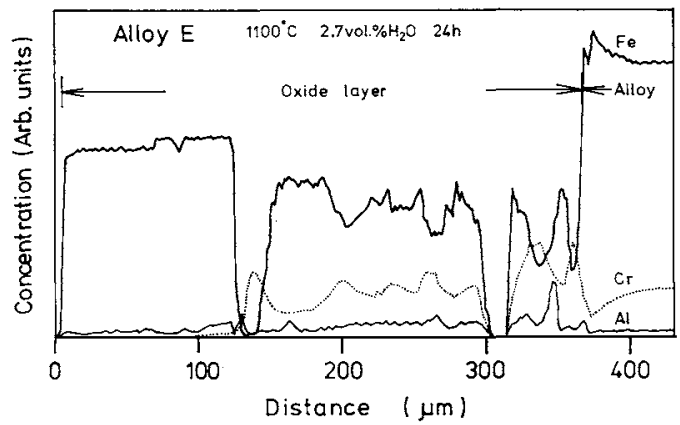

Fig.9 Microprobe scans showing the concentration profiles for $\mathrm{Fe}, \mathrm{Cr}$ and $\mathrm{Al}$ along the dark line in Photo.2(d).

示すよらな異常酸化物を形成する，Fig.9から明らかな よ5に，A1の濃度は内層，外層ともに高く，内層ではか なり集積している所もみられる。この内層はX線回折の結 果から他の合金と同様 $(\mathrm{Fe}, \mathrm{Cr})_{2} \mathrm{O}_{3}$ と同定されたが， $\mathrm{Al}$ の酸化物，たと充ば， $\alpha-\mathrm{Al}_{2} \mathrm{O}_{3}$ あるいは $\mathrm{FeO} \cdot(\mathrm{Cr}, \mathrm{Al})_{2} \mathrm{O}_{3}$ としては検出することは出来なかった。

\section{IV. 考察}

wet $\mathrm{O}_{2}$ 中での供試材の高温酸化挙動は非常に複雑であ るが，異常酸化発生様式の特徵をIIIの項で述べたように， (1)比較的低温かつ多湿条件で B，D合金化みられる全面 発生型すな⿰七刀大 Type X (Photo.1 (a)，(f)) と(2)Photo.1 (b)，(c)，(g)火示されている比較的高温であらわれる周柬 発生型すなわら Type Y に大別することができる. Type $\mathrm{X}$ の場合は耐酸化性が悪く，皮膜中に $\mathrm{Al}$ の集積がみられ ずそその挙動が $\mathrm{A}$ 合金に質的に類似していることから $\mathrm{A} 1$ 添加効果は殆んぞあらわれていない，Type Yの場合は Type X に比して発生時期が途いことに加えて，その後 の酸化速度む小さく，皮膜中には内部酸化に上る Al が集 積している。このように，耐酸化性と内部酸化により形成 する $\mathrm{A} 1$ の集積は密接に関係していることがらかがわれ る。ところが，先に $\operatorname{dry~} \mathrm{O}_{2}$ 中の酸化挙動们ついて報告 ${ }^{(6)}$ したように， $\mathrm{Al}$ の添加量が少ない場合は $\alpha-\mathrm{Al}_{2} \mathrm{O}_{3} か ゙$ 適切 に分散した，いわゆる，内部酸化層の形成が酸化速度の
低減化に有效に働くと考えられる。このことから，上飞述 べた皮膜中の $\mathrm{A} 1$ の集積が耐酸化性に直接寄与したもので 苟るとするのは妥当でなく, wet $\mathrm{O}_{2}$ 中の場合も dry $\mathrm{O}_{2}$ 中 々同様の機構が慟いているものと推察される。したがっ て, 皮膜中の $\mathrm{A} 1$ の集積は異常酸化を起こす前には合金中 に分散していた粒子が，異常酸化の進行とともに，拉そら くGiggins ら (9)が TD NiCについての研究で若干ふれて いるよらな機構によって粒子が移動集団化して形成したも のと考穴られる。

Fig.10は $1100^{\circ} \mathrm{C}$ に和ける水分の影響を示す。C 合金 は全試験湿度において，また B 合金は $1.4 \%$ 安で dry $\mathrm{O}_{2}$ 中と比較して殆えど変化はない。



Fig.10 Effect of water vapour contents on oxidation of $\mathrm{Fe}-14 \mathrm{Cr}-\mathrm{Al}$ alloys oxidized at $1100^{\circ} \mathrm{C}$ for $24 \mathrm{~h}$ in $1 \mathrm{~atm}$ wet oxygen.

一方, $\mathrm{A} 1$ 量の多い $\mathrm{D}, \mathrm{E}$ 合金では㩆著な水分の影響が 欢られる。ここで, 水分の影響を受けないのは $\alpha-\mathrm{Al}_{2} \mathrm{O}_{3}$ 粒 子が分散した内部酸化層が上く発達し， $\mathrm{Cr}_{2} \mathrm{O}_{3}$ 濃度の高い 皮膜が形成している場合である。

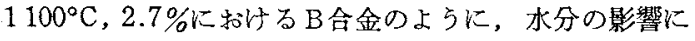
よる酸化速度の上昇との相対的な意味で内部酸化層の発達 が暒れる場合は試料全面で水分の影響を受ける。他方，D の一部や $\mathrm{E}$ 合金炕特けるよらに内部酸化層の形成よりるむ 乙万 $\alpha-\mathrm{Al}_{2} \mathrm{O}_{3}$ の集皘内層を形成しやすい場合には，水分 の影響を試料の周囲部で強く受けている。

さて，内部酸化層の形成と wet $\mathrm{O}_{2}$ 中の酸化抵抗の関係 についての以上の状況を明確にするために，次のような追 加実験を行なった。 まず, B, D 合金を $1200^{\circ} \mathrm{C}$, dry $\mathrm{O}_{2}$ 中 で 1 時間酸化して $\alpha-\mathrm{Al}_{2} \mathrm{O}_{3}$ 粒子の分散した内部酸化層を 形成させ, 続いて, $1000^{\circ} \mathrm{C}, 2.7 \%$ て $24 \mathrm{~h}$ (合計 $25 \mathrm{~h}$ ) 酸化

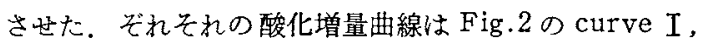
Fig.4 の curve II に示す. Photo.3はこれらの外観を示 すが, Photo.1(a)，(f) との羑異浽顕著である。すなわち。 $\mathrm{A} 1$ が内部酸化することによって $\mathrm{Cr}_{2} \mathrm{O}_{3}$ を主体とする保護 


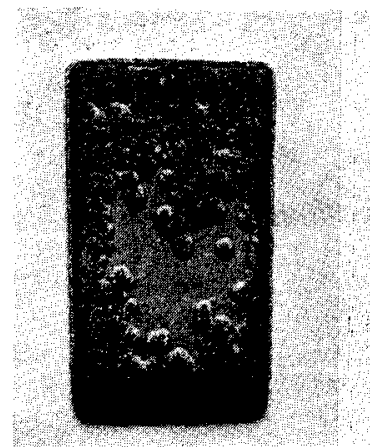

Alloy B

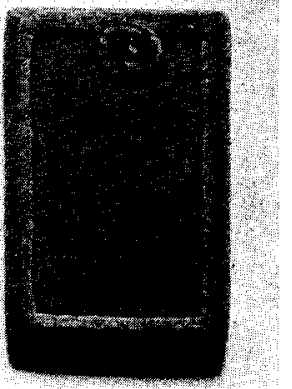

Alloy D
Photo. 3 Appearance of specimens of alloys $B$ and $\mathrm{D}$ oxidized at $1000^{\circ} \mathrm{C}$ for $24 \mathrm{~h}$ in $1 \mathrm{~atm}$ oxygen with $2.7 \mathrm{vol} \% \mathrm{H}_{2} \mathrm{O}$ after preoxidation at $1200^{\circ} \mathrm{C}$ for $1 \mathrm{~h}$ in 1 atm dry oxygen.

性のよい皮膜の生成が容易になり，同時にその安定性が 增すことによって耐酸化性が向上するという考方方が， wet $\mathrm{O}_{2}$ 中での酸化についてる有効であると推察される. ただし，この場合， $\alpha-\mathrm{Al}_{2} \mathrm{O}_{3}$ からなる内部酸化層形成の過 程そのものが $\mathrm{Cr}_{2} \mathrm{O}_{3}$ の発生を助長するのか，あるい，

既に形成された内部酸化粒子が核発生を容易にするの かは秃た明らかではない、Fe-15Cr-REM 合金において Nakamura(10) はY 生の siteになっているのではないかと考它ており， Flower b ${ }^{(11)}$ は Ni-30Cr 合金比ついて比較的低温 (450〜 $700^{\circ} \mathrm{C}$ ) に批いてではあるが，合金の粒界，非金属介在物 や slip steps で Cr が優先酸化することを高生電子蹎微 鏡中での酸化観察で確認している。一方，各種の酸化物粒 子をあらかじめ含有した Ni-Cr 合金の高温酸化に柿いて 酸化物粒子の $\mathrm{Cr}_{2} \mathrm{O}_{3}$ の優先形成への効果が報告(9)(12)(13) れておりまた，Hf，Ti や Zr を含む Co-Cr 系でも同様 の效果が観察されている(14)，Fe-Cr 系についても同様の 効果が期待されるとこるであり，Wright ら ${ }^{(15)}$ は粉末法で 作製した $\mathrm{Fe}-16 \mathrm{Cr}-\mathrm{Y}_{2} \mathrm{O}_{3}$ 合金について報告している。乙 かし，本実験でも確認されているように内向拡散する。の 役割を含めて機構の解明は今後待たれる。本実験の範囲 内に括いて，C合金が最も厦れた耐酸化性を有するのは dry $\mathrm{O}_{2}$ 中の場合と同様に内部酸化が最む有効化働くため であると考兄られる。また，B，D合金が低温多湿(例宇ば $1000^{\circ} \mathrm{C}, 2.7 \%$ ) 条件で急速に酸化すること，すなわち，

Type X の挙動を示すのは水分の影響が強くあらわれた 典型例である。 $1000^{\circ} \mathrm{C}$ において両合金ともに若下の内部 酸化を起こし，初期淿は $(\mathrm{Fe}, \mathrm{Cr})_{2} \mathrm{O}_{3}$ からなる保護皮膜が 形成される。しかし， dry $\mathrm{O}_{2}$ 中の場合と比較してこの皮 膜中の $\mathrm{Fe}_{2} \mathrm{O}_{3}$ 濃度は高くなって拈り買常酸化が発生しや すい状態にある。一方，内部酸化作用からくる修復 $\mathrm{Cr}_{2} \mathrm{O}_{3}$ 層の形成速度は小さく，保護性皮膜持続のための均衡は容 易に失なわれ急速酸化に至ると考吕られる。A $\mathrm{Al}$ 量の少な いB合金と多いD合金を同一に処理しているよらである
が，基本的には dry $\mathrm{O}_{2}$ 中での挙動についてさきに報告し たような差異が介在しているであるらことは十分考党られ る. $\mathrm{Fe}-\mathrm{Cr}$ 合金の高温酸化挙動几ついての一連の報告の 中で Caplan ら ${ }^{(1)(2)}$ は水分の影響について次のように説明 している.tp. $446(27 \mathrm{Cr})$ に和外るように皮膜中の $\mathrm{Cr}_{2} \mathrm{O}_{3}$ 濃度が高い場合には， $\mathrm{H}^{+}$イオンが陽イオンの空格子点を 占拠して Cr 拉散量を低減させ，酸化速度が低下する。一 方，低 $\mathrm{Cr}$ 合金の上 $5 K \mathrm{Fe}_{2} \mathrm{O}_{3}$ 濃度が高い場合は $\mathrm{OH}^{-} 1$ オンが ○ーーイオンを置換することによって陽イオンの空格 子点の濃度を高める結果, 酸化速度が加速される。しか し, 彼ら ${ }^{(4)}$ は後に, 高純度の Fe-26Cr 合金について調 へ，酸化速度は水分の影響を殆んど受けないといら結果を 得ている。この場合は， $\mathrm{Cr}_{2} \mathrm{O}_{3}$ 濃度の高い皮膜を形成する C合金についての結果と上く一致する．水分によって酸化 速度が加速される場合についての彼らの推論は Type X で代表される急速酸化の一つの説明となり得るむのである 5。急速酸化持続の説明として，Fujii $5^{(3)}$ が提案した “dissociative mode” に代表されるガスの transport mechanism は Kvernes ら ${ }^{(5)}$ の場合と同様，本実験の結 果と矛盾しないるのと考光られる。しかしながら，B，D 合金の酸化增量曲線にもみられるよらに, Type Xの異 常酸化挙動を示す場合, その影響か酸化の初期段階から現 われて Cr の優先酸化が牒制されるなぞ水分の基本的作用 については不明な点が多い，また，水分の量が増すにつれ て異常酸化すなわち breakaway が容易になるのは酸化皮 膜中に括ける $\mathrm{Fe}$ の富化に伴ら多孔性の增加や，主たる要 因と思われる皮膜の割れが “dissociative reaction”(3) しくは類似の反応によって，ごく小規模にではあるがす で存在していると思われる皮膜内の橵小空吵中で発生す る $\mathrm{H}_{2}$ ガスによって促進されるなどの原因が考えられるが 詳細は解明されていない。

$\mathrm{A} 1$ 童の多いE合金で dry $\mathrm{O}_{2}$ 中での挙動と質的な相違 は認められないが，Photo.1(h)，(i)Kみられるよらな周 囲からの wart 発生までの時間が短縮されること、および その成長を加速するなど水分の影響が観察される。これは Fe-Si-A1 合金 ${ }^{(16)}$ と扑ける wart についてる同榚の報告が あり，Fe 基合金江共通の現象であるものと考兄られる。

\section{V. 結 言}

少量の $\mathrm{A} 1(0.1,0.3,0.8$ および $2.0 \%)$ を含を $\mathrm{Fe}-14 \mathrm{Cr}$ $\mathrm{Al}$ 合金厄ついて, 900 1 $200^{\circ} \mathrm{C}$, 水蒸気 $(0.7,1.4$ 打よび 2.7 vol\% $\left.\mathrm{H}_{2} \mathrm{O}\right)$ を含有した 1 気圧酸素中で $24 \mathrm{~h}$ 酸化を行 ない，酸化挙動への水分の影響を重量变化測定，X線回折， EPMA 扣よび走查電顕観察により研究した。

温度と湿度が共に低い場合は酸素中での酸化挙動と殆ん ど変化は認められないが，低温でも湿度が增すと酸化速度 が急增し，また高温では少量の水分でも強く影響を受け る. $0.3 \% \mathrm{Al}$ 合金は最も優れた耐酸化性を示した。これ 
はよく発達した $\alpha-\mathrm{Al}_{2} \mathrm{O}_{3}$ からなる内部酸化層によって優 先形成する $\mathrm{Cr}_{2} \mathrm{O}_{3}$ 皮膜の保護性によるもので西ると考克 られる。

$0.1 \% \mathrm{Al}$ 合金は $2.7 \mathrm{vol} \% \mathrm{H}_{2} \mathrm{O}$ を除いて $1000^{\circ} \mathrm{C}, 1100^{\circ} \mathrm{C}$ ではdry $\mathrm{O}_{2}$ 中と比較して酸化增量, 生成皮膜構造ともに 殆えど氷分の影響を受けない。 $0.3 \% \mathrm{~A} 1$ 合金については $1100^{\circ} \mathrm{C}$ 以下では $2.7 \mathrm{vol} \% \mathrm{H}_{2} \mathrm{O} に$ にいてさ克も殆んど变 化が双られない，0.8\%A1 合金では $1000^{\circ} \mathrm{C}$ 以上の温度， 湿度で影響を受けるよらになる。 $2.0 \% \mathrm{~A} 1$ 合金に対して

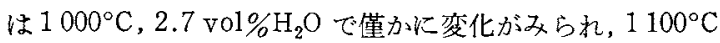
以上になると水分の增加と共汇試料周辺から異常酸化が発 生し, 酸化增量も增すようになる。異常酸化皮膜の構造は 内層, 外層からなって打り，外層は外側飞 $\mathrm{Fe}_{2} \mathrm{O}_{3}$, 内側飞 $\mathrm{Fe}_{3} \mathrm{O}_{4}$ ，内層は一部 $(\mathrm{Fe}, \mathrm{Cr})$ スピネル型の複酸化物毛認 められるが主体は $(\mathrm{Fe}, \mathrm{Cr})_{2} \mathrm{O}_{3}$ と同定された。 $1000^{\circ} \mathrm{C}$, 2.7 vol\% $\mathrm{H}_{2} \mathrm{O}$ の上うに比較的低温，多湿条件飞打いて， 0.1 扎よび $0.8 \% \mathrm{Al}$ 合金では異常酸化が全表面でほぼー 様に発生し，皮膜の内層中に $\mathrm{A} 1$ の集積がみられない。 こ礼に対して，0.3\% A1 合金の $1200^{\circ} \mathrm{C}$, 全試験湿度, $0.1 \% \mathrm{~A} 1$ 合金の例えば $1200^{\circ} \mathrm{C}, 1.4 \mathrm{vol} \% \mathrm{H}_{2} \mathrm{O}$ 叔よび $0.8 \% \mathrm{~A} 1$ 合金の例之ば $1100^{\circ} \mathrm{C}, 1.4 \mathrm{v} 01 \% \mathrm{H}_{2} \mathrm{O}$ では異常 酸化は試料周辺部から起こり，二の皮膜内層には共通乙 て，Al の集積がみられた。この集積 $\mathrm{A} 1$ は異常酸化が発 生するまで炕すで形成している $\alpha-\mathrm{Al}_{2} \mathrm{O}_{3}$ の内部酸化層 が異常酸化の進行と共隹合したるのと推察された。後者 の異常酸化様式をとる典型例は $0.3 \% \mathrm{~A} 1$ 合金である。

本研究の遂行にあたり，終始協力いたたいた当研究所研
究員太田 隆, 过 栄治両氏に心から感謝の意を表しま す。



(1) D. Caplan and M. Cohen: J. Metals, 4(1952), 1057.

(2) D.Caplan and M.Cohen : Corrosion, 15(1959), $141 \mathrm{t}$.

(3) C. T. Fujii and R. A. Meussner : J. Electrochem. Soc., $111(1964), 1215$.

(4) D. Caplan and M.Cohen : J. Electrochem.Soc., $112(1965), 471$.

(5) I. Kvernes, M. Oliveira and P. Kofstad: Corros.Sci., 17 (1977), 237.

(6) 池偉夫, 岡部広文, 讷 栄治：日本金属学会誌, $42(1978), 509$.

(7) C. S. Tedmon, Jr. : J. Electrochem. Soc., 113 (1966) , 766 .

(8) D.Caplan and M.Cohen : J. Electrochem. Soc., $108(1961), 438$.

(9) C. S. Giggins and F. S. Pettit : Met. Trans., 2 (1971), 1071.

(10) Y.Nakamura: Met. Trans., 5(1974), 909.

(11) H.M.Flower and B.A.Wilcox : Corros.Sci., 17 (1977), 253.

(12) M. S. Seltzer, B. A. Wilcox and J. Stringer : Met.Trans., 3(1972), 2391.

(13) I. G. Wright, B. A. Wilcox and R. I. Jaffee: Oxid. Met., 9(1975) , 275.

(14) D. P. Whittle, M. E. El-Dahshan and J. Stringer : Corros.Sci., 17(1977), 879.

(15) I.G. Wright and B. A. Wilcox : Met. Trans., 5 (1974), 957.

(16) W.E.Boggs : Oxid.Met., 10(1976), 277.

\section{純チタン板の Cup and Cone 型破壊過程における}

\section{剪断変形集中帯についで}

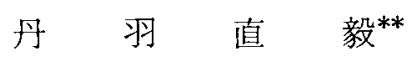

Naotake Niwa: Shear Bands in the "Cup and Cone" Fracture Process of Pure Titanium Plate. The process of "cup and cone" fracture was examined in commercial pure titanium plate pulled in uniaxial tension. Direct and continuous observation of the fracture process was possible because the fracture process of titanium plate used in this experiment was completed almost in two-dimensional state like plane strain state.

The fracture process is summarized as follows : the formation of shear bands which intersect in the center of the necked portion of a specimen occurs prior to the onset of fracture. These macroscopic shear bands are composed of a number of highly localized fine bands of intense shear deformation in layers and along the direction of the macroscopic shear bands.

\footnotetext{
** 東京大学工学部総合試験所 (Engineering Research Institute,Faculty of Engineering, University of Tokyo, Tokyo)

* 1978 年 4 月日本金属学会東京大会比一部発表
} 